\title{
Hans Jonas and Vasily Grossman: Reflections on the Human Condition after Auschwitz
}

\author{
Roberto Franzini Tibaldeo (Scuola Superiore Sant'Anna - Pisa) ${ }^{1}$
}

\section{A biographical Introduction}

\subsection{Hans Jonas}

Hans Jonas (1903-1993)2 was trained as a philosopher in Freiburg and Marburg with Edmund Husserl, Martin Heidegger, and Rudolph Bultmann. He received his $\mathrm{PhD}$ in 1928 with a dissertation on The Concept of Gnosis (Jonas 1930), as an anticipation of a broader research then to be published in Gnosis and the Spirit of Late Antiquity (Jonas 1934; 1954). His promising academic career was interrupted by Hitler's Machtergreifung in 1933. The very same year Jonas, who at that time was a fervent Zionist, decided to leave Germany, whereas his parents and his brother Georg decided to stay. From 1935 Hans established himself in Palestine. Jonas' father died at the beginning of 1938, and in that same year, during the Krystallnacht (9-10 November 1938), Georg was caught by the Nazis and interned as a prisoner in Dachau. This event interrupted Jonas' mother's arrangements for their departure from Germany: she wanted to obtain a visa for her son Georg, first. However, she failed. What she succeeded in achieving was the permission that Georg left for Palestine, but on condition that she handed over her own visa to her son. Hans tried to obtain another visa for his mother from abroad, but in vain. Jonas' mother paid for her generosity and devotion to her sons with her own life, since in 1942 she was interned in the Łódź/Litzmannstadt ghetto and then deported to Auschwitz, where she was murdered.

During the war Hans took up arms against Nazism by enrolling in the Jewish Brigade Group of the British Army. After the war Jonas, with his wife and daughter, strived to establish themselves in Palestine, but then decided to move to Canada in search of better conditions for life and more encouraging academic perspectives. Meanwhile Jonas shifted his main philosophical research from ancient Gnosticism to issues related to the phenomenon of life.

1 This article is one of the outcomes of the Research Unit "Social Asymmetries and Political Inclusion: Concepts, Methods, and Policies," Scuola Superiore Sant'Anna, Pisa (PRIN 2010-2011; Local Coordinator: Barbara Henry, National Coordinator: Laura Bazzicalupo).

${ }^{2}$ For an autobiographical account, see Jonas (2008), Wiese (2007), Bonaldi (2009), Becchi (2010), and Hintzen (2012). 
After publishing several articles on this topic, in 1966 he finally released a book on The Phenomenon of Life (Jonas 1966). As for his academic career, in 1955 he became professor of philosophy at the Graduate Faculty of Political and Social Science of The New School in New York. During the Sixties and Seventies his research mainly focused on issues such as bioethics, ethics of technology, and environmental ethics. In 1979 he published his masterwork The Imperative of Responsibility (Jonas 1984) and in 1985, the book Technique, Medicine, and Ethics (Jonas 1985). He devoted his last philosophical efforts to enquiries into the notion of God such as The Concept of God after Auschwitz: A Jewish Voice (1987) ${ }^{3}$ and Philosophical Enquiries and Metaphysical Hypotheses (Jonas 1992).

Jonas died on 5 February 1993 in New Rochelle (near New York) where he resided. Only a few days before he had been awarded the Nonino Prize at Percoto (Udine) in Italy, for his commitment and enthusiasm in fostering culture and philosophy. Jonas attended the ceremony and delivered a touching lecture on Racism in the Light of the Threat to Mankind ${ }^{4}$.

\subsection{Vasily Grossman}

Vasily Grossman (1905-1964) was born in Berdichev (Ukraine) into an emancipated Jewish family and did not receive a traditional Jewish education. Berdichev was one of the largest and liveliest Jewish communities in the former Russian Empire until World War II when, in September and October 1941, the Nazis exterminated about 20,000 to 30,000 Jews who had not been able to evacuate. Among these was Grossman's mother.

In his youth Grossman witnessed the effects of the Bolshevik Revolution: the Civil War of 1918-1921, the famine of 1920-1922, and the peasant war of 1919-1923. His parents, and later Grossman himself, supported the Revolution as an opportunity for Jews to gain equality of opportunities (Garrard-Garrard 1996, 60-61). Indeed, under the former tsarist domination Jews were not only heavily discriminated, but periodically suffered from brutal pogroms.

In 1923 Grossman moved to Moscow, in order to study chemistry at the University, but he soon lost enthusiasm for science. Instead he longed to become a writer, but this was particularly difficult due to his poor economic conditions. However, he succeeded in his efforts: his first articles were published in 1928 in the Nasha Gazeta and the Pravda; they dealt with the economic, cultural, and social conditions of the Uzbekistan population and indirectly aimed at supporting the industrialisation process decreed by Stalin (Garrard-Garrard 1996, 81). Indeed, Grossman's literary career began in the worst time: In 1930-1932 there was Stalin's Terror Famine and in 1937-1938 there was the Great Terror. Stalin was tightening his control over society, and

${ }^{3}$ English translation published in Jonas (1996, 131-143).

4 Published in Böhler (1994, 25-29; see Wolters 2013). 
the arts and literature were powerful means in order to secure this result. Therefore, Grossman had to engage a struggle to write honestly and yet succeed in getting his works published "without writing to order (sotsialny zakaz)" (Garrard-Garrard 1996, 108). Although the cost was high, his efforts were finally rewarded and he succeeded in gaining public recognition as a writer.

In 1941 Grossman volunteered for the front, where he spent more than 1,000 days as a combat correspondent for the Red Star (Krasnaya Zvezda), the official newspaper of the Red Army. Grossman covered the major events of the Eastern front, including the Battle of Moscow, the Battle of Stalingrad (where he experienced a unique fraternal spirit and enthusiasm among people of different ethnic backgrounds), the Battle of Kursk, and the Battle of Berlin. In January 1944, on his way to Berlin with the advancing Red Army, he arrived in Berdichev and learned about the fate of his mother and thousands of other Jews 5 . In September 1944 Grossman arrived at the ash remains of the NaziGerman Vernichtungslager of Treblinka, where 800,000 people had been murdered. He collected the first eyewitness accounts of what later became known as the Shoah and published a touching report: The Hell of Treblinka $(1944)^{6}$. The year before Grossman had been invited by Ilya Ehrenburg to join the new Literary Commission, which reported to the Jewish Anti-fascist Committee. The aim of the Commission was to collect eyewitness and survivor accounts about the Shoah on Soviet soil and to publish them in The Black Book. Although originally the project had received Stalin's approval, after the war things changed and the project was even suppressed at his own order 7 . Stalin's reluctance to recognise the specific Jewish nature of Nazis' atrocities against civilians was one of the causes that cracked Grossman's belief in the Soviet system ${ }^{8}$.

After the war Grossman devoted himself to writing a novel on the war, whose title was supposed to be Stalingrad. However, the book was opposed by key editors of Soviet journals due to political and ideological reasons. Grossman had to rewrite the book in depth and change its title to For a Just Cause. He finally succeeded in having the novel published in 1952 in the

5 See Grossman's account The Murder of the Jews of Berdichev (composed in 1944), in Ehrenburg-Grossman (2002, 12-19).

${ }^{6}$ English translation published in Grossman (2010,16-162).

7 However, a version of the book was successfully sent abroad during the war, and finally published in Israel (1980) and USA (1981). See Ehrenburg-Grossman (2002) and Garrard-Garrard (1996, $177 \mathrm{ff}$. and 392).

8 The other critical issues pointed out in Grossman's works - issues that, indeed, according to Stalin ought not to be publicly discussed - were the collaboration of the Ukrainian people with the Nazis (and, in particular, soldiers who had served the Red Army and then surrendered to the Germans) and the complete story of Stalingrad i.e., the role played by "the soldiers who fought and died there, but whose sacrifice was already being set aside so that Stalin and the Communist party could take credit for the victory" (Garrard-Garrard 1996, 194; see as well Ellis 1994). 
journal Novy Mir in instalments. But the novel was savagely and officially attacked by the Pravda. Grossman started to fear for his own safety. Stalin's death in 1953 filled Grossman with the hope that things might change. He started working on his masterpiece, Life and Fate, the second part of his novel about Stalingrad. He wished to tell more of the truth about the battle and the fate of Soviet Jews than he could do in For a Just Cause. Unfortunately, things did not change: not only was his novel denied publication, but on 14 February 1961 the KGB literally arrested all the manuscripts of Life and Fate. This was a devastating blow for Grossman, who felt as if he had been "buried alive" (Garrard-Garrard 1996, 263 ff.). He died of stomach cancer in 1964. Life and Fate (Grossman 2011a) was first published in 1980 in Switzerland thanks to a friend of Grossman, to whom he had previously given a copy of the manuscript to hide. The same happened to Everything Flows, which was smuggled abroad and published in Russian in 1970 in Germany (Grossman 2011b).

\section{Unde malum? Why Auschwitz?}

Both the lives and reflections of Hans Jonas and Vasily Grossman deal with the Shoah and its dreadful uniqueness. As many other intellectuals, Jonas and Grossman endeavour to enquire into the meaning of the Shoah. This investigation recalls of course Job's question on the origins of evil (unde malum?), but it cannot end with the answer traditionally provided, namely theodicy. Indeed, states Jonas, what has now to be investigated is not "the problem of imperfection and natural necessity but that of positive evil, which implies a freedom empowered by its own authority independent of that of God" (Jonas 1996, 141). And what we have to contend with at this hour is precisely "the fact and success of deliberate evil rather than the inflictions of the blind, natural causality - the use of the latter in the hands of responsible agents (Auschwitz rather than the earthquake of Lisbon)" (Jonas 1996, 141).

Besides-states Grossman-the Shoah highlights a shocking uniqueness: what sounds utterly different is Auschwitz's (or Treblinka's) infernal distinctiveness, a feature for which it is almost impossible to come up with a due and satisfactory explanation:

Today the witnesses have spoken; the stones and the earth have cried out aloud. And today, before the eyes of humanity, before the conscience of the whole world, we can walk step by step around each circle of the Hell of Treblinka, in comparison with which Dante's Hell seems no more than an innocent game on the part of Satan (Grossman 2010,123).

The conveyor belt of Treblinka functioned in such a way that beasts were able methodically to deprive human beings of everything to which they have been entitled, since the beginning of time, by the holy law of life. First people were robbed of their freedom, their home and their motherland; they were transported 
to a nameless wilderness in the forest. Then, on the square by the station, they were robbed of their belongings, of their personal letters, and of the photographs of their loved ones. After going through the fence, a man was robbed of his mother, his wife and his child. After he had been stripped naked, his papers were thrown on to a fire; he had been robbed of his name. He was driven into a corridor with a low stone ceiling; now he had been robbed of the sky, the stars, the wind and the sun. Then came the last act of the human tragedy-a human being was now in the last circle of the Hell that was Treblinka. The door of the concrete chamber slammed shut. The door was secured by every possible kind of fastening: by locks, by hooks, by a massive bolt. It was not a door that could be broken down (Grossman 2010,144).

Moreover, Jonas and Grossman are aware that further issues have to be preliminarily posed in order to enquire into the Shoah. Given that the infernal magnitude of the evil experienced at Auschwitz and elsewhere is unheard of and hardly believable, how can it be described and accounted for? How to overcome the "aporia of Auschwitz"9 (Agamben 1999, 12)? Is it really possible? And finally why enquire into Auschwitz after all? For what purpose?

Notwithstanding differences, for both intellectuals the Shoah calls on their duty to comment on the survivors' testimony: the more Auschwitz challenges human understanding and eventually risks being misinterpreted, the more important it is to shed light on it (Jonas); the more the memory of the Shoah risks being cancelled or forgotten, the more it has to be actively recollected (Grossman). Moreover, Jonas and Grossman seem to confirm the correctness of Agamben's analysis, according to which the endeavour to comprehend the Shoah copes with an essential lacuna in the structure of testimony itself:

At a certain point, it became clear that testimony contained at its core an essential lacuna; in other words, the survivors bore witness to something it is impossible to bear witness to. As a consequence, commenting on survivors' testimony necessarily meant interrogating this lacuna or, more precisely, attempting to listen to it (Agamben 1999, 13) ${ }^{10}$.

I believe that Jonas' and Grossman's reflections on the Shoah and on the sense of its testimony can be interpreted as an attempt to listen to "what is unsaid" in Auschwitz, as precisely suggested by Agamben (Agamben 1999, 14).

9 The "aporia of Auschwitz" is defined as follows: The truth of what happened in the extermination camps "is to the same degree unimaginable, that is, irreducible to the real elements that constitute it. Facts [are] so real that, by comparison, nothing is truer; a reality that necessarily exceeds its factual elements" (Agamben 1999, 12; see as well Badii-D'Andrea 2014).

10 For some critical remarks on Agamben's reflections, see: Fraser (2000) and Chare (2006). 
In The Concept of God after Auschwitz Jonas recalls that, traditionally speaking, the Jewish meaning of "witness" indicates that "precisely the innocent and the just suffer the worst ... Through their sacrifice shone the light of promise, of the final redemption by the Messiah to come" (Jonas 1996, 132133). However, Auschwitz marks an irretrievable rupture and rift:

Nothing of this is still of use in dealing with the event for which "Auschwitz« has become the symbol. Not fidelity or infidelity, belief or unbelief, not guilt or punishment, not trial, witness and messianic hope, nay, not even strength or weakness, heroism or cowardice, defiance or submission had a place there. Of all this, Auschwitz, which also devoured the infants and babes, knew nothing; to none of it (with rarest exceptions) did the factory-like working of its machine give room. Not for the sake of faith did the victims die (as did, after all, "Jehovah's Witnesses«), not because of their faith or any self-affirmed bend of their being as persons were they murdered. Dehumanization by utter degradation and deprivation preceded their dying, no glimmer of dignity was left to the freights bound for the final solution, hardly a trace of it was found in the surviving skeleton specters of the liberated camps (Jonas 1996, 133) ${ }^{11 .}$

The abyss of the Shoah, with all its spiral of dehumanisation, is something that even the most faithful accounts of eyewitnesses cannot help in bridging or fully understanding. Thus, what about those who, like Jonas, were not eyewitnesses, and yet feel an urge and responsibility to testimony? How can they succeed? As I shall try to explain in greater detail in the following paragraphs, Jonas' solution is to revisit the very notion of "witness," along with its subject (who is the witness) and object (what is witnessed), as a preliminary step in order to achieve a renewed understanding of God, and this is in order to gain a glimmer of understanding of the riddle of witnessing the Shoah.

As for Grossman, his initial reaction to the Shoah highlights two core beliefs. The first is the memory of the past as the writer's main duty:

It is infinitely painful to read this. The reader must believe me when I say that it is equally hard to write it. "Why write about it then?" someone may well ask. "Why recall such things?." It is the writer's duty to tell the terrible truth, and it is a reader's civic duty to learn this truth. To turn away, to close one's eyes and walk past is to insult the memory of those who have perished. Only those who have learned the whole truth can ever understand against what kind of monster our great and holy Red Army has entered into mortal combat (Grossman 2010, 150).

11Similarly Grossman in Life and Fate: "When you think about new-born babies being killed in our own lifetime, all the efforts of culture seem worthless" (Grossman 2011a, 362. See also D'Andrea-Badii (2010) and Dries (2012). 
The last statement highlights Grossman's second belief-the one that postwar events would have brought him to revise and finally repudiate: the conviction that Soviet Russia is somehow different from Nazi-Germany, namely morally superior and this is thanks to Communism and the "Spirit of Stalingrad", that provide enough vigour to prevent racism and the discriminations nurtured by the "imperialist idea of exceptionalism—of racial, national and every other kind of exceptionalism" (Grossman 2010, 161). Initially, Grossman puts the blame for the Shoah especially on Germany and the "traditional German chauvinism" (Grossman 2010, 120). Nevertheless, the writer is also aware that what happened at Auschwitz and Treblinka calls for a more thorough analysis, one that addresses precisely the "aporia of Auschwitz":

Scholars, sociologists, criminologists, psychiatrists and philosophers-everyone is asking how all this can have happened. How indeed? Was it something organic? Was it a matter of heredity, upbringing, environment or external conditions? Was it matter of historical fate, or the criminality of the German leaders? Somehow the embryonic traits of a racial theory that sounded simply comic when expounded by the second-rate charlatan professors or pathetic provincial theoreticians of nineteenth-century Germany-... all the nonsense about the superiority of the Germans to every other race on earth, all the cheap nonsense that seemed so comical, such an easy target for journalists and humourists-all this, in the course of only a few years, ceased to seem merely infantile and was transformed into a threat to mankind. It became a deadly threat to human life and freedom and a source of unparalleled crime, bloodshed and suffering. There is much now to think about, much that we must try to understand (Grossman 2010,161).

Thus, as a provisional result of his meditation, Grossman states that: "It is not enough now to speak about Germany's responsibility for what has happened. Today we need to speak about the responsibility of every nation in the world; we need to speak about the responsibility of every nation and every citizen for the future" (Grossman 2010, 161). As we shall see, Grossman's works aim at fulfilling precisely this task.

\section{Enquiring into the Meaning of the Shoah}

Auschwitz, Treblinka and the Shoah give Jonas and Grossman the opportunity to carry out an in-depth investigation into the abyss of human nature. Despite reciprocal differences, their reflections deal with analogous topics, which I shall now try to single out and analyse in greater detail.

\subsection{The vulnerability of life}


One of the basic achievements of Grossman's and Jonas' reflections is the vulnerable character of life. What vulnerability means is the fact that life is something perishable, precarious, fragile, and exposed to uncertainty and death. As stated by Hans Jonas in his remarkable essay on The Phenomenon of Life (1966):

living substance, by some original act of segregation, has taken itself out of the general integration of things in the physical context, set itself over against the world, and introduced the tension of "to be or not to be» into the neutral assuredness of existence. It did so by assuming a position of hazardous independence from the very matter which is yet indispensable to its being: by divorcing its own identity from that of its temporary stuff, through which it is yet part of the common physical world. So poised, the organism has its being on condition and revocable (Jonas 1966, 4).

Life is intrinsically precarious and uncertain; it is an effort whose reality "is at bottom continual crisis" (Jonas 1966, 5) and whose essence highlights a paradoxical relation to death: "Life carries death in itself, not in spite of, but because of, its being life, for of such a revocable, unassured kind is the relation of form and matter upon which it rests" (ibid. 5). Thus, life can be understood as an unrestrained effort to prevent its own annihilation: "Intrinsically qualified by the threat of its negative it [= life] must affirm itself, and existence affirmed is existence as a concern" (ibid. 4). Organic life is a risky adventure, whose existence relies on the accomplishment of a basic task (selfpreservation) thanks to the employ of a certain extent of power over reality. Life is (self-)concern and action; in a word: freedom-namely, a degree of liberty that is by no means absolute, since "the organic form stands in a dialectical relation of needful freedom to matter" (Jonas 1966, 80)12.

According to Jonas, the dialectical and vulnerable essence of life characterises all living beings, including human beings. However, the uniqueness of the human being's self-concern, action, freedom, and power is such that its consequences at a social and collective level have gained epochal relevance. What Jonas has in mind here is related to modern technology-an issue that highlights "an infinite forward-thrust of the race" (Jonas 1984, 9) and whose development risks to degenerate, due to "an excess of power to »do" and thus an excess of offers for doing" (Jonas 1974, 181) and to an unrestrainable tendency to "the cumulative self-propagation of the technical change of the world" (Jonas 1984, 7; see also Frogneux 2012) ${ }^{13}$. According to Jonas, these features emphasise a core difference between the present age and

12 On Jonas' philosophical biology, see among others Frogneux (2001) and Franzini Tibaldeo (2009).

${ }^{13}$ For an interesting reflection on the relationship between modernity, technology and the Shoah see: Dries (2012). 
the traditional framework: nowadays, an undeniable fact has come to light; that is:

the critical vulnerability of nature to man's technological intervention-unsuspected before it began to show itself in damage already done. This discovery ... alters the very concept of ourselves as a causal agency in the larger scheme of things. It brings to light, through the effects, that the nature of human action has de facto changed, and that an object of an entirely new order-no less than the whole biosphere of the planet-has been added to what we must be responsible for because of our power over it (Jonas 1984, 6-7).

The "critical vulnerability of nature" is one of the most eloquent signs of the times, whereas once the basic belief was exactly the opposite:

The immunity of the whole, untroubled in its depth by the importunities of man, that is, the essential immutability of Nature as the cosmic order, was indeed the backdrop to all of mortal man's enterprises, including his intrusions into that order itself. Man's life was played out between the abiding and the changing: the abiding was Nature, the changing his own works (Jonas 1984, $3)$.

In these reflections on modern technology "also the spectres of Auschwitz" plays its part (Jonas 1996, 134). The altered nature of human action not only generates consequences in terms of environmental threats, but also questions the sense of human liberty in itself. Auschwitz seems to pose precisely such issue: on the one hand the human being shares the vulnerable fate of life and nature, while on the other hand man is endowed with a power over reality thanks to which he can actively contribute to the critical degeneration of vulnerability, and this is especially through inconceivable and dreadful actions perpetrated against other human beings, as highlighted by the Shoah. How can we decipher this aporia between the "natural" vulnerability of life and the "critical" vulnerability fostered by the human being's free will? How can this ambivalent abyss of human liberty be understood? As we shall see, tackling this problem forces Jonas to accomplish a peculiar enquiry into the notion of God.

Vasily Grossman's reflections indicate a strong similarity with those of Jonas. The dramatic experience of the Shoah stresses precisely the vulnerable feature of life:

Leather, paper, cloth-everything of use to man was of use to these beasts. It was only the most precious valuable in the world - human life-that they trampled beneath their boots. Powerful minds, honourable souls, glorious childish eyes, sweet faces of old women, proudly beautiful girlish heads that nature had toiled age after age to fashion-all this, in a vast silent flood, was condemned to the abyss of non-being. A few seconds was enough 
to destroy what nature and the world had slowly shaped in life's vast and tortuous creative process (Grossman 2010, 133-134).

The vulnerable value and beauty of (human) life stands out against the surroundings of (human) evil. To some extent, this contrast recalls the aporia of vulnerability experienced by Jonas. Grossman develops the issue through a dialogue between two characters of his masterpiece, Life and Fate (posthumously published in 1980): the physicist of Communist faith, Dmitry Petrovic Chepyzhin, and his pupil (and alter ego of the author), Viktor Pavlovich Shtrum. According to the first, the evolution of life is a process that coherently, optimistically and infallibly results in the human being as the sovereign of the universe:

In my opinion, life can be defined as freedom. Life is freedom. Freedom is the fundamental principle of life ... Now, as soon as freedom appeared, it began to evolve. It evolved along two lines. First: man has more freedom than protozoa. The whole evolution of the living world has been a movement from a lesser to a greater degree of freedom. This is the very essence of evolution ... And there's a second, quantitative, line of evolution ... The mass of animate matter will constantly increase at the expense of that of inanimate matter. The terrestrial globe will gradually come to life ... Then the other planets will come to life ... then the animation of inanimate matter will take place on a galactic scale. Inanimate matter will be transformed into free, living matter. The universe will come to life. Everything in the world will become alive and thus free. Freedom-life itself-will overcome slavery ... One day man will be endowed with all the attributes of the deityomnipresence, omnipotence and omniscience ... But man won't just stop there. After attaining equality with God, he will begin to solve the problems that were beyond God. He will establish communication with rational beings from the highest level of evolution, beings from another space and another time to whom the whole history of humanity seems merely a dim flicker ... The abyss of time and space will be overcome. Man will finally be able to look down on God (Grossman 2011a, 690-691).

On the contrary, Shtrum, who believes there are no such grounds for optimism, strives for the recognition of an inconvenient truth, one that neither under Stalin nor later on was to be particularly welcome:

What I felt as I listened to you was not joy, but utter despair. We think we're so wise ... . And yet on this very day the Germans are slaughtering Jewish children and old women as though they were mad dogs. And we ourselves have endured 1937 and the horrors of collectivization - famine, cannibalism and the deportation of millions of unfortunate peasants... Once, everything seemed simple and clear. But these terrible losses and tragedies have confused everything. You say man will be able to look down on God - but what if he also becomes able to look down on the Devil? 
What if he eventually surpasses him? You say life is freedom. Is that what people in the camps think? What if the life expanding through the universe should use its power to create a slavery still more terrible than your slavery of inanimate matter? Do you think this man of the future will surpass Christ in his goodness? That's the real question. How will the power of this omnipresent and omniscient being benefit the world if he is still endowed with our own fatuous self-assurance and animal egotism? Our class egotism, our race egotism, our State egotism and our personal egotism? What if he transforms the whole world into a galactic concentration camp? (Grossman 2011a, 691-692).

Apart from the insinuation about the analogy between the Communist and Nazi branches of totalitarianism-an utterly uncomfortable reflection and a taboo when Grossman was composing Life and Fate ${ }^{14}$ - what I find remarkable is the author's capacity to provide one of the best and most convincing arguments against cosmic and ethic optimism. As already recalled by Jonas, this argument is related to the historical event of Auschwitz, along with its aporia. Grossman agrees with Jonas in singling out the twofold feature-which is indeed typically human-of power and vulnerability. What happened at Auschwitz provides enough evidence that there is nothing that can prevent the human desire of equalling God to turn into something evil. In other words, the Shoah provides historical evidence to the idea that human nature and liberty are essentially ambivalent and supplies a peculiar insight into the essential relationship between vulnerability and ambivalence.

An aspect Grossman analyses further is the one related to "State egotism" that characterises totalitarian States, along with their ambivalence and diabolic annihilation of vulnerability. The issue is intertwined with antiSemitism, which-according to Grossman-"is a measure of the contradictions yet to be resolved. It is a mirror of the failings of individuals, social structures and State systems. Tell me what you accuse the Jews of - I'll tell you what you're guilty of" (Grossman 2011a, 484). According to Grossman there are at least three different levels of anti-Semitism:

Firstly, there is a relatively harmless everyday anti-Semitism. This merely bears witness to the existence of failures and envious fools. Secondly, there is social anti-Semitism. This can only arise in democratic countries. Its manifestations are in those sections of the press that represent different reactionary groups, in the activities of these groups-for example, boycotts of Jewish labour and Jewish goods-and in their ideology and religion. Thirdly, in totalitarian countries, where society as such no longer exists, there can arise State anti-Semitism. This is a sign that the State is looking for the support of fools, reactionaries and failures, that it

14 The analogy is especially developed in a remarkable dialogue between the Nazi Obersturmbannführer Liss and the Communist Mikhail Mostovskoy (Grossman 2011a, 391-403). See: Dell'Asta (2007) and Todorov (2003, 48-73). 
is seeking to capitalize on the ignorance of the superstitious and the anger of the hungry (Grossman 2011a, 486-487).

Grossman focuses especially on the third level, which is indeed the most critical and vicious. Moreover, it highlights the State's willingness to actively subdue the vulnerability and precariousness of individuals and groups in order to achieve unrestrained power ${ }^{15}$. This project gives rise to the following escalation, which cannot but end in the utter extermination of the vulnerable:

The first stage of State anti-Semitism is discrimination: the State limits the areas in which Jews can live, the choice of professions open to them, their right to occupy important positions, their access to higher education, and so on. The second stage is wholesale destruction. At a time when the forces of reaction enter into a fatal struggle against the forces of freedom, then antiSemitism becomes an ideology of Party and State-as happened with Fascism (Grossman 2011a, 487).

Just like Jonas, what Grossman experiences as the result of his deconstructive enquiry is the unability-after Auschwitz-of those optimistic and rather dull views of liberty and history as events chiefly endowed with reasonableness, rationality, and metaphysical stability. Quite the contrary, the power gained by human beings has ended in disclosing the dreadful extent of human liberty's ambivalence, in banning tout court from history notions such as rationality and stability, and in possibly subverting and distorting traditional values:

I have seen the unshakeable strength of the idea of social good that was born in my own country. I saw this struggle during the period of general collectivization and again in 1937. I saw people being annihilated in the name of an idea of good as fine and humane as the ideal of Christianity. I saw whole villages dying of hunger; I saw peasant children dying in the snows of Siberia; I saw trains bound for Siberia with hundreds and thousands of men and women from Moscow, Leningrad and every city in Russiamen and women who had been declared enemies of a great and bright idea of social good. This idea was something fine and noble-yet it killed some without mercy, crippled the lives of others, and separated wives from husbands and children from fathers. Now the horror of German Fascism has arisen. The air is full of the groans and cries of the condemned. The sky has turned black; the sun has been extinguished by the smoke of the gas ovens. And even these crimes, crimes never before seen in the Universe-even by Man on Earth-have been committed in the name of good (Grossman 2011a, 406-407).

As a further disturbing result of the subversion caused by contemporary totalitarianism, Grossman highlights the vanishing of guilt and personal

15 Grossman's short story The Old Teacher (1943) provides a hint of the social effects of State anti-Semitism (Grossman 2010, 84-115; see also Ravenna 2014). 
responsibility. A key passage of Grossman's last novel, Everything Flows (composed from 1955 to 1963), singles out precisely this issue. The excerpt refers to an imaginative trial against "four Judases", namely four categories of informers and betrayers, who-according to Grossman-are to be held equally responsible for the Soviet totalitarianism. However, the reply of the Judases to the accusations of being personally involved in the dreadful events of Stalinism sounds like a complete discharge of their own responsibilities ${ }^{16}$ :

Prosecutor: ... What do you all think? Do you really not consider yourselves in the least to blame?

INFORMER: Allow me to reply. For all its outward simplicity, your question is, in fact, far from simple. In the first place, it is pointless. What use is it now to attempt to find out who is guilty with regard to crimes committed in the era of Stalin? That would be like emigrating to the moon and then starting a lawsuit about title deeds to a plot of land here on earth. On the other hand, if we are to take the line that the two eras are not so distant from each other and that, sub specie aeternitatis, they stand "almost side by side" - as the poet said - then many other complexities arise. Why are you so eager to condemn those, like us, who are small and weak? Why not begin with the State? Why not try the State? Our sin, after all, is its sin ... And please also explain one other thing. Why have you waited till now to raise these questions? You've known us all long enough. In Stalin's lifetime you were only too glad to spend time with us ... Yes, like us, you participated in the Stalin era. Why must we, who were participants, be judged by you, who were also participants? Why must you determine our guilt? Do you not see where the difficulty lies? Maybe we really are guilty, but there is no judge who has the moral right to discuss the question of guilt. Remember how Leo Tolstoy said that no one in the world is guilty? But in our State things are different: everyone is guilty - there is not one innocent person anywhere ... So is it for you, Comrade Prosecutor, to accuse us? Only the dead, only those who did not survive, have the right to judge us. But the dead do not ask questions; the dead are silent. So please allow me to answer your question with another question ... What is the reason for this vile, universal weakness? Your weakness, our weakness, everyone's weakness? This mass submissiveness? (Grossman 2011b, 1127-1147).

This is the plain outcome of the totalitarian epoch: the individuals and their attributes (personal freedom and responsibility, desires, cultural and religious diversity, etc.) seem to have been eradicated and substituted by grey, faceless

16 It is noteworthy that the justifications provided by the Judases somehow resemble the arguments of those Nazi party officials who were actually prosecuted after the Second World War (see, for instance, Arendt 2003, 227 ff.; Agamben 1999, 21-24; Arendt 2006, 47 ff. and 270 ff.; Wiegrefe 2014; Bohr et al. 2014; see also Wolters 2004). This confirms once more the soundness of Grossman's thesis of the similarity between Nazi Germany and Soviet Russia. 
men endowed with banal features-such as widespread weakness and mass submissiveness - and yet capable of accomplishing unprecedented evil in the name of "good". Ambivalence and vulnerability undergo a similar deterioration: they no longer highlight the human being's (ordinary) uniqueness, but are involved in the dreadful and critical distortions of the latter which occurred in the 20 th century.

\subsection{The immortality of humanity}

Although for both Jonas and Grossman the Shoah represents far more than an event among others and is a Stolperstein (stumbling block) that cannot be simply forgotten or erased, neither of them believes Auschwitz has the last word. Even though it may give rise to distorted historical effects (and indeed Auschwitz exemplifies the horrible extent of this falsification), yet the ambivalence of freedom is what distinguishes the human being in itself, and thus it cannot be simply disposed of. For both Jonas and Grossman it is inconceivable to relinquish human freedom only because of its faults. But how to cope with the ambivalence of human freedom after Auschwitz? How to deal with such frightful background and with the possibility of further misuse of liberty? And what about the related issue of good? How is it still possible to search for the good after Auschwitz? What transformation does that notion undergo? And what about the related belief shared by both authors in humanity's immortality?

Grossman's answer to the issue regarding good is quite explicit:

Good is to be found neither in the sermons of religious teachers and prophets, nor in the teachings of sociologists and popular leaders, nor in the ethical systems of philosophers... And yet ordinary people bear love in their hearts, are naturally full of love and pity for any living thing ... Yes, as well as this terrible Good with a capital "G", there is everyday human kindness. The kindness of an old woman carrying a piece of bread to a prisoner, the kindness of a soldier allowing a wounded enemy to drink from his water-flask, the kindness of youth towards age, the kindness of a peasant hiding an old Jew in his loft. The kindness of a prison guard who risks his own liberty to pass on letters written by a prisoner not to his ideological comrades, but to his wife and mother. The private kindness of one individual towards another; a petty, thoughtless kindness; an unwitnessed kindness. Something we could call senseless kindness. A kindness outside any system or social or religious good. But if we think about it, we realize that this private, senseless, incidental kindness is in fact eternal ... . Even at the most terrible times, through all the mad acts carried out in the name of Universal Good and the glory of States, time when people were tossed about like branches in the wind, filling ditches and gullies like stones in an avalanche - even then this senseless, pathetic kindness remained scattered throughout life like atoms of radium (Grossman 2011a, 407-408). 
Although Grossman defines this variety of good as a "mad, blind, kindness" (Grossman 2011a, 409) ${ }^{17}$, what he hints at is no ingenuous or irenic belief, but a conviction that has been inconceivably corroborated through the experience of the Shoah:

Yes, after despairing of finding good either in God or in Nature, I began to despair even of kindness. But the more I saw of the darkness of Fascism, the more clearly I realized that human qualities persist even on the edge of the grave, even at the door of the gas chamber. My faith has been tempered in Hell. My faith has emerged from the flames of the crematoria, from the concrete of the gas chamber. I have seen that it is not man who is impotent in the struggle against evil, but the power of evil that is impotent in the struggle against man. The powerlessness of kindness, of senseless kindness, is the secret of its immortality (Grossman 2011a, 410).

And similarly in An Armenian Sketchbook (written in 1962 and published in 1988) while reporting the experience of a former inmate of a Soviet gulag:

He said a lot about how, though reduced almost to the level of animals, people in the camps still felt pity for one another, about how those who were on their last legs did all they could to help others who were on their last legs, about how neither blizzards, nor temperatures of minus forty, nor national differences ever got in the way of human kindness (Grossman 2013, pos. 756-758).

This basic faith in human nature and its immortality recalls Grossman's The Sistine Madonna (composed in 1955, but published only in 1989), a remarkable reflection on art and atrocity. Grossman's thoughts originate from Raphael's painting Sistine Madonna (1512), which he had the opportunity to contemplate in 1955 during an exhibition in Moscow at the Pushkin Museum (Grossman 2010, 164) ${ }^{18}$. The writer begins by stating clearly the correct nature of his considerations, which are by no means animated by a transcendent perspective upon life ${ }^{19}$ :

In his Madonna Raphael has revealed the mystery of maternal beauty. But the secret of the painting's inexhaustible life lies elsewhere ... . The Madonna's beauty is closely tied to earthly life ... . It is a universal beauty. This Madonna is the soul and mirror of

\footnotetext{
${ }^{17}$ For a comment on Grossman's idea of kindness, see Todorov $(2003,69-72)$.

18 This and other works of art had been requisitioned by the Red Army during the Second World War and were about to be returned to the Gemäldegalerie in Dresden (Garrard-Garrard 1996, 328).

19 Raphael's Sistine Madonna gives rise to a lively debate in the $19^{\text {th }}$ century Russia. Among the intellectuals that take part in the discussion, there are F. Dostoyevsky and L. Tolstoy. According to the first, The Sistine Madonna is the sublime expression of an ideal mystical experience, while Tolstoy interprets the painting in mere immanent human terms (Bori 1990; Curletto 2006, 42-44; Mrówczyński-Van Allen 2013; Pirazzoli 2013).
} 
all human beings, and everyone who looks at her can see her humanity ... . I believe that this Madonna is a purely atheistic expression of life and humanity, without divine participation (Grossman 2010, 165-166).

Grossman does not forget the dark shadow recently cast by the Shoah on history. He is aware that the Madonna's beauty and humanity confront exceptionally hard times. Yet, precisely for this reason, Grossman believes that the Madonna is a symbol standing out against the adversities of history and endowed with universal relevance: "Looking at the Sistine Madonna, our own epoch glimpses its own fate ... A wolfish time had come, the time of Fascism. It was a time when people led wolfish lives and wolves lived like people" (Grossman 2010, 168-170). Albeit the coeval dark times, the Madonna witnesses the persistence of humanity and its thorough difference from inhumanity, whose champions are individuals like Hitler and Stalin, who are explicitly mentioned by Grossman, and thus very much alike in their criminal brotherhood. ${ }^{20}$ Neither Hitler nor Stalin are able to look into the Madonna's eyes or recognise her (Grossman 2010, 170, 172). Instead, "we, we people, we recognized her, and we recognized her son too. She is us; their fate is our own fate; mother and son are what is human in man" (Grossman 2010, 172; also Riconda 2007 \& Maddalena 2007). And what does the Madonna represent? What is she the symbol for? She symbolises precisely the immortality of life and humanity:

The painting speaks of the joy of being alive on this earth; this too is a source of its calm, miraculous power. The whole world, the whole vast universe, is the submissive slavery of inanimate matter. Life alone is the miracle of freedom. And the painting also tells us how precious, how splendid life has to be, and that no force in the world can compel life to change into some other thing that, however it may resemble life, is no longer life. The power of life, the power of what is human in man, is very great, and even the mightiest and most perfect violence cannot enslave this power; it can only kill it. This is why the faces of the mother and child are so calm: they are invincible. Life's destruction, even in our iron age, is not its defeat ... We live in troubled time. Wounds have not yet healed ... Over the ditches that contain the bodies of murdered Jewish children and mothers the earth is still shifting, still settling into place ... . The Madonna has suffered all this together with us-for she is us, and her son is us (Grossman 2010, 172-173).

20 Besides, as admitted by the Communist party boss for all ideological matters, Mikhail A. Suslov, in a conversation with Grossman held in the Kremlin on 23 July 1962, the "direct comparisons between us [Soviet Russia] and Nazi Germany" is one of the reasons that make it "impossible to publish your book [Life and Fate], and it will not be published" (Garrard-Garrard 1996, 358; see as well Grossman 1997). 
Grossman is aware of the fact that the Shoah implacably questions everybody's personal responsibility. Besides, he confesses that the doubt cast on the impossibility of personal innocence in times of totalitarianism is indeed a "difficult and terrible question" (Grossman 2010, 173)21. Grossman is perfectly aware of his faults, nor does he attempt to excuse them ${ }^{22}$. He believes, however, that the cruel present calls for a higher task:

We will say, »There has been no time crueller than ours, yet we did not allow what is human in man to perish «. Seeing the Sistine Madonna go on her way, we preserve our faith that life and freedom are one, that there is nothing higher than what is human in man. This will live forever and triumph (Grossman 2010, 173174).

In conclusion, what Grossman achieves from his enquiry into the Shoah is a renewed belief in the godless immortality of humanity, which in addition strongly supports his effort to actively recollect Auschwitz and Treblinka. However, the historical events that occurred in the post-war Soviet Russia (the success of Stalinisation and then the Destalinisation with its fallacy and false hope ${ }^{23}$ roughly challenge Grossman's faith. While working on his masterpiece Life and Fate, the KGB arrests all materials related to it (notes, copies of the manuscript, even the spools of his typewriter, etc.). As a result, the writer and the truth he strived to tell are buried alive. Yet, these tribulations confirm the soundness of his faith, as highlighted by the following excerpts written by Grossman in his last years. The first dates back to 1961 and is addressed to his deceased mother:

I am you, dear Mama, and as long as I live, then you are alive also. When I die, you will continue to live in this book [Life and Fate], which I have dedicated to you and whose fate is closely tied with your fate ... . Working [on Life and Fate] over the past ten years, I have been thinking about you constantly. My novel is dedicated to my love and devotion to people, and that is why it is dedicated to

${ }^{21}$ As already highlighted, this challenging and terrible question is at the origins of the noteworthy trial against the "four Judases". The trial ends with the following verdict: "No one among the living is innocent. All the living are guilty ... You, the defendant, are guilty, and you, the prosecutor, are guilty, and I, the writer-I who am thinking about the defendant, the prosecutor and the judge - am guilty" (Grossman 2011b, pos. 11811184).

22 This issue is brilliantly developed in Garrard-Garrard 1996. Among his wrong acts, Grossman particularly regrets having failed to save his mother from her fate during the war and having spent too little efforts to save some of his parents and friends from the ferocity of Stalin's Terror in the Thirties.

23 See for instance the following statements pronounced by Suslov during a conversation with Grossman in 1962: "We have revealed the mistakes that accompanied the cult of Stalin, but we will never condemn Stalin for fighting the enemies of the Communist party and of the state. We condemn him only because he waged war against his own people [i.e., the Party itself]" (Garrard-Garrard 1996, 359). 
you. For me, you are humanity, and your terrible fate is the fate and destiny of humanity in this inhumane time (Garrard-Garrard 1996, 353).

The second quotation belongs to Everything Flows:

... at this time of the total triumph of inhumanity it has become clear that everything created by violence is senseless and useless. It exists without a future; it will leave no trace. This is my faith (Grossman 2011b, pos. 3082-3084).

Finally, the third is a remarkable excerpt from Grossman's personal testament, An Armenian Sketchbook, written in early 1962. Grossman is struck by an unexpected revelation while talking with an unknown semi-literate old Armenian:

The supreme human gift is beauty of soul; it is nobility, magnanimity and personal courage in the name of what is good. It is a gift possessed by certain shy, anonymous warriors, by certain ordinary soldiers but for whose exploits we would cease to be human (Grossman 2013, pos. 1528-1530).

Humanity is the common feature unifying all human beings, who belong to different cultures and nationalities. However, the accomplishment of humanity relies on the most fundamental of all values, which is (individual and collective) freedom: "Communication between people of different nationalities enriches human society and makes it more colourful. But this process of enrichment cannot take place without freedom. When people are free, communication between different nations is fruitful and beneficial" (Grossman 2013, pos. 315-317). Then, Grossman recalls once again the vulnerability and precariousness of human liberty, which is menaced by the "blind obsession of national character" (Grossman 2013, pos. 328) and "the rigidity of national stereotypes" (Grossman 2013, pos. 352-353). To start with, these threats have to be recognised and overcome, so that what is "more truly human" can be given the opportunity to flourish:

... what matters is to discover the riches of human hearts and souls; what matters is the human content of poetry and science, the universal charm and beauty of architecture; what matters is human courage and nobility ... . It is the struggle for human spiritual and material wealth, the struggle for freedom of thought and expression, the struggle for a peasant's freedom to sow what he wants to sow, for everyone's freedom to enjoy the fruits of their own work-this is the true struggle for national dignity" (Grossman 2013, pos. 353-357).

These reflections disclose the full extent of Grossman's humanistic faith and profound wisdom, which he achieved through pain and sorrow. As remarked by Emmanuel Lévinas, these are thoughts that definitely bear witness to 
Grossman's recognition of peace "as awakeness to the precariousness of the other" (Lévinas 1996, 167).

Let us now turn to Hans Jonas' reflections on immortality and its connection with the good. As anticipated in $\S 3.1$, the human being highlights a distinctive feature: on the one hand, human life and freedom are rooted within the natural and cosmic phenomenon of life, and share its very vulnerable essence; on the other hand, they transcend this biological basis and succeed in amplifying the possibilities offered by organic life and freedom. In particular, human liberty manifests an unprecedented and ambivalent feature, one that gives rise to critical issues impacting on the very essence of life. How is the human being's distinctiveness to be highlighted in greater detail? What relationship does it exhibit with immortality? What are the consequences on the issue of good?

According to Jonas, the uniqueness of the human being can be expressed as follows:

Man models, experiences, and judges his own inner state and outward conduct after the image of what is man's. Willingly or not he lives the idea of man-in agreement or in conflict, in acceptance or in defiance, in compliance or in repudiation, with good or with bad conscience (Jonas 1966, 185; Frogneux 2012).

As a result, the distinctiveness of human freedom is such, that it provides its owner with the possibility of measuring "his being against terms that transcend the immediate situation" (Jonas 1966, 186) and even of surpassing the restraints of temporality. This is precisely what distinctive human enterprises such as religion, ethics, and metaphysics have in common: they "are attempts, never completed, to meet and answer the question [concerning human nature] within an interpretation of total reality" (Jonas 1966, 187). Thus, Jonas puts forward the following hypothesis regarding the overall sense of human liberty: "We feel, temporality cannot be the whole story, because in man it has an inherently self-surpassing quality, of which the very fact and fumbling of our idea of eternity is a cryptic signal" (Jonas 1966, 268). And:

The fact that by cosmic scales man is but an atom is a quantitative irrelevancy: his inner width can make him an event of cosmic importance. The reflection of being in knowledge may be more than a human event: it may be an event for being itself and affect its metaphysical condition. In Hegelian language: a "coming to itself" of original substance (Jonas 1966, 283-284).

In other words, Jonas believes that a thorough understanding of the human being's uniqueness, along with its capacity to transcend any given situation, can be achieved only through a tentative investigation into the very fundament of transcendence and liberty, namely God. Indeed, Jonas believes that the symbol of man's transcendent uniqueness, namely the "image of 
man", is precisely due to God, who created it. But what does this mean? What does "creation" mean here? Rather than adhering to the traditional viz. active and dynamic interpretation of the creative act ${ }^{24}$, Jonas underlines a different aspect, one related to God's primeval decision to renounce "his own being, divesting himself of his deity" (Jonas 1966, 275) and omnipotence, and giving himself over to the chance and risk and endless variety of becoming 25 . In this way, God lets the cosmos (and life, human freedom, and the "image of man") be and evolve, so that the eternal realm can finally "come to itself" and "recover its plenitude" (Jonas 1966, 275, 284). However, the Creation yielded by God's self-denial and self-forfeiture cannot be predetermined by any specific project or intelligent design, nor by any movement leading to any prefixed goal. On the contrary, the created cosmos is characterised by utter contingency, and its future is open-ended and still to be decided. This is the cosmos where human beings foster their ambivalent liberty and are responsible for the consequences of their deeds (Jonas 1966, 278-281).

Despite its open-ended and contingent feature, the cosmic being ought not to be understood in terms of pure ethical indifference or ontological nihilism. As regards God, although impotent and self-negated, he is certainly not indifferent to what takes place within the Creation. Indeed, he manifests worry, hope, interest towards the cosmos and its evolving character, and gains strength through its adventures. Mainly, this happens as soon as "the first stirring of life" (Jonas 1966, 275) appears along with its distinctive feature:

It is the world-accident for which becoming deity had waited and with which its prodigal stake begins to show signs of being redeemed. From the infinite swell of feeling, sensing, striving, and acting, which ever more varied and intense rises above the mute eddyings of matter, eternity gains strength, filling with content

24 Among the theoretical difficulties of the traditional doctrine of creation, there is indeed the existence of evil. This issue becomes particularly delicate after Auschwitz, as brilliantly highlighted for instance by Grossman: "After all, it is not writers, poets or composers who created the soul of Eichmann .... It is not they who are responsible for the general senseless madness of the universe. We have the right to ask the divine mocker this question: in whose image and likeness was humanity created? In whose image were Hitler and Himmler created? It was not men and women who gave Eichmann his soul; men and women merely made an Obersturmbannführer's uniform for him. And there were many other of God's creations who covered their nakedness with the uniforms of generals and police chiefs, or with the silk shirts of executioners. We should call on the Creator to show more modesty. He created the world in a frenzy of excitement. Instead of revising his rough drafts, he had his work printed straightaway" (Grossman 2013, pos. 10081016).

25 Jonas' narration is rooted into the Kabbalistic tradition and is to be understood as an innovation of the latter (Jonas 1996, 142). See Frogneux (2001, 233 242; Bonaldi, 2007; Bongardt 2008; Frogneux 2011; Borghese Keene 2014; BecchiFranzini Tibaldeo 2014). 
after content of self-affirmation, and the awakening God can first pronounce creation to be good (Jonas 1966, 275-276).

As we know, the essence of life is characterized by precariousness, instability, and vulnerability - in a word, mortality. But what the mythical account adds is the following remark:

Yet it is precisely through the briefly snatched self-feeling, doing, and suffering of finite individuals, with the pitch of awareness heightened by the very press of finitude, that the divine landscape bursts into color and the deity come to experience itself (Jonas 1966, 276).

And the Deity's self-experience takes place with even more intensity thanks to the appearance, within the cosmic adventure, of mankind:

And then he [God] trembles as the thrust of evolution, carried by its own momentum, passes the threshold where innocence ceases and an entirely new criterion of success and failure takes hold of the divine stake. The advent of man means the advent of knowledge and freedom, and with this supremely double-edged gift the innocence of the mere subject of self-fulfilling life has given way to the charge of responsibility under the disjunction of good and evil. To the promise and risk of this agency the divine cause, revealed at last, henceforth finds itself committed; and its issue trembles in the balance (Jonas 1966, 277).

Therefore, Jonas' account of creation evidences that vulnerability is the basic feature not only of life, but also of God himself, and this is for the following reasons: the primeval self-negation of God highlights his acceptance of vulnerability as his essence and fate. Indeed, due to this oblational decision, the Deity provides the ultimate foundation for the cosmic contingency and especially for the peculiar vulnerability of the phenomenon of life. Moreover, God accepts to bind his own being to the cosmic adventures of evolution and, as soon as life appears, mortality. Due to his primeval self-denial, he decides to put his own existence at stake in the cosmic adventure, and ultimately in the hands of human liberty. He is, indeed, vulnerable to the unforeseeable outcomes of these adventures, that are out of his control. He cannot but accept their openness and ambivalence, and this is precisely because he himself is at the origins of such features. The essential relationship between vulnerability and ambivalence is already highlighted by the "mortal" essence of life (see $\S$ 3.1). However, the connection becomes even more manifest and dramatic due to mankind: it is, indeed, thanks to human beings that the cosmic opportunity offered by God can be "transfigured or possibly even disfigured" (Jonas 1966, 275). God is himself vulnerable, since his being is essentially in the hands of man: 
The image of God, haltingly begun by the universe, for so long worked upon-and left undecided-in the wide and then narrowing spirals of pre-human life, passes with this last twist, and with a dramatic quickening of the movement, into man's precarious trust, to be completed, saved, or spoiled by what he will do to himself and the world (Jonas 1966, 277).

What are the consequences of this fresco for human liberty and responsibility? Jonas answers as follows:

Having given himself whole to the becoming world, God has no more to give: it is man's now to give to him. And he may give by seeing to it in the ways of his life that it does not happen, or not happen too often, and not on his account, that "it repented the Lord" (Gen. 6:6-7) to have made the world ${ }^{26}$ (Jonas 1966, 279; Jonas 1996, 142).

Then Jonas adds a statement that recalls Grossman's belief in the existence and effectiveness of good:

This may well be the secret of the "thirty-six righteous ones" whom, according to Jewish tradition, the world shall never lack (Sanhedrin $97 \mathrm{~b}$; Sukkah $45 \mathrm{~b}$ ): that with the superior valency of good over evil, which, we hope, obtains in the non-causal logic of things there, their hidden holiness can outweigh countless guilt, redress the balance of a generation and secure the serenity of the invisible realm (Jonas 1966, 279).

And, similarly to Grossman, Jonas details further his reflections in order to secure his belief against the accusation of optimistic superficiality ${ }^{27}$. Jonas is aware of the fact that the superiority of good over evil ought to cope with Auschwitz, namely with "the gassed and burnt children," "the defaced, dehumanized phantoms of the camps", and "all the other, numberless victims of the man-made holocausts of our time" (Jonas 1966, 279). The Shoah undeniably casts a shadow of anxiety over the ambivalence of human liberty and responsibility. If-on the one hand-this is something perfectly consistent with the essence of freedom and with the overall open-ended feature of the cosmic adventure (incidentally, this means that there is no way of pre-emptively guaranteeing a happy ending to the latter), yet-on the other hand-the unheard of degree of ambivalence gained by present day humankind compels additional philosophical efforts and a renewed degree of

${ }^{26}$ Jonas' idea that it is humanity that ought to help God rather than the converse has its origins in the account of Etty Hillesum, a young Dutch Jewess who was murdered in Auschwitz (Jonas 1996, 191-192; see also Hillesum 2002).

${ }^{27}$ Indeed, I believe that the following account provides a sound argument against Agamben's objection to Jonas' conciliatory and optimistic theodicy (Agamben 1999, 20). 
awareness. Jonas proposes the following corollary to his tentative metaphysical account:

the image of God is in danger as never before, and on most unequivocal, terrestrial terms. That in these terms an eternal issue is at stake together with the temporal one - this aspect of our responsibility can be our guard against the temptation of fatalistic acquiescence or the worse treason of après nous le deluge. We literally hold in our faltering hands the future of the divine adventure and must not fail Him, even if we would fail ourselves. Thus in the dim light at the end of our wandering we may discern a twofold responsibility of man: one in terms of worldly causality, by which the effect of his deed extends for some greater or shorter length into a future where it eventually dissipates; and a simultaneous one in terms of its impact on the eternal realm, where it never dissipates .... . Although the hereafter is not ours, nor eternal recurrence of the here, we can have immortality at heart when in our brief span we serve our threatened mortal affairs and help the suffering immortal God (Jonas 1966, 281).

In conclusion, Jonas' view of human responsibility as a cooperative and empathetic effort with the immortal, impotent and suffering God is quite different from Grossman's atheistic belief in the immortality of humanity. Indeed, I believe this dissimilarity is at the origins of the contrast between Grossman's belief that evil and violence "will leave no trace" (Grossman 2011b, pos. 3084), and Jonas' opposite persuasion that human liberty has an "impact on the eternal realm, where it never dissipates" (Jonas 1966, 281). Nevertheless, both perspectives share strong similarities due to their common enquiry into the meaning of the Shoah and its consequences on issues, such as vulnerability, immortality, humanity, freedom and good.

\section{The Human Condition after Auschwitz}

After having outlined Jonas' and Grossman's views on the Shoah, along with their mutual similarities and differences, what I endeavour to carry out is a concluding critical enquiry. I wish to verify if Jonas' and Grossman's reflections are somehow consistent with Giorgio Agamben's relatively recent meditation on the Remnants of Auschwitz (Agamben 1999). My analysis shall focus on two main questions that are indeed closely related one another: what does "human" signify after Auschwitz? And: What paradigm do Jonas and Grossman's reflections on the Shoah embody?

According to Agamben, Auschwitz's "unsaid" relies on its unprecedented distinctiveness, which is expressed as follows: "the camp is the absolute verification of Nazi politics, which, in the words of Goebbels, was precisely the 'art of making possible what seems impossible'" (Agamben 1999, 77). What does this mean? In what sense does the Shoah represent the becoming 
possible of something allegedly impossible? Agamben's answer: “This means that humans bear within themselves the mark of the inhuman, that their spirit contains at its very center the wound of non-spirit, non-human chaos atrociously consigned to its own being capable of everything" (Agamben 1999, 77). The event of Auschwitz-and in particular the related metamorphosis of the prisoner into a dehumanised shadow, called in the jargon of the camp der Muselmann, literally "the Muslim"28_"makes it forever impossible to distinguish between man and non-man" (Agamben 1999, 47). The Muselmann is the embodiment of the infernal novelty of Auschwitz: he "is the site of an experiment in which morality and humanity themselves are called into question" (Agamben 1999, 63), and this precisely in the sense that enquiring into the meaning of the Shoah and thinking after the Shoah requires to undergo a thorough conceptual revolution:

Auschwitz marks the end and the ruin of every ethics of dignity and conformity to a norm. The bare life to which human beings were reduced neither demands nor conforms to anything. It itself is the only norm; it is absolutely immanent. And "the ultimate sentiment of belonging to the species" cannot in any sense be a kind of dignity. The good that the survivors were able to save from the camp-if there is any sense in speaking of a "good" here-is therefore not dignity. On the contrary, the atrocious news that the survivors carry from the camp to the land of human beings is precisely that it is possible to lose dignity and decency beyond imagination, that there is still life in the most extreme degradation. And this new knowledge now becomes the touchstone by which to judge and measure all morality and all dignity (Agamben 1999, 69).

The immanence of "bare life" along with the paradox exemplified by the Muselmann-namely the fact that on the one hand bare life is a condition of extreme dehumanisation and degradation, while on the other hand it is still life ${ }^{29}$-is Auschwitz's main dreadful achievement. What does this mean? Before Auschwitz "human" life (bios) is generally understood as manifesting a thorough differentia from natural or bare life $(z o \bar{e})^{30}$. And those human efforts, such as ethics, law and politics, that aim at identifying and ruling human nature, presuppose that unequivocal differentia. But then Auschwitz modifies this framework deeply and forever. The Muselmann suggests precisely that the former definition of "human" as a bios (namely, a form of life endowed with specific features) as opposed to zoe is simply untenable. Moreover, the Muselmann exhibits that the "human" comes close to conjoining with zoē, with all its paradox and ambivalence. Thanks to the testimony of the Muselmann,

28 The origin of the term is explained in Agamben $(1999,44-45)$.

29 "The Muselmann is the non-human who obstinately appears as human; he is the human that cannot be told apart from the inhuman" (Agamben 1999, 81-82).

30 The difference between bios and zōe is elucidated in Agamben (1998). 
after the Shoah it is not possible to restore the previous theoretical belief in the plain differentia of man. This, however, does not mean that the human being ought to utterly get rid of his or her own specificity, but that the latter has to be understood in the light of its dialectical, paradoxical and ambivalent relationship with "bare life". This is indeed the "lesson of Auschwitz" (Agamben 1999, 133) and its point of no return: as a consequence of its view of the human being, Auschwitz revokes any abstract, fixed and clear demarcation between normality and exceptionality, possible and impossible, the ordinary and the extreme, humanity and inhumanity. Hence, any normative viz. ethical, political, or metaphysical feature insisting on the reciprocal unambiguous otherness of those opposites, becomes simply meaningless and finally fails to understand the very essence of the human being and finally the Shoah. According to Agamben, Auschwitz gives rise to the following hermeneutical dispute:

$\ldots$ it is possible to gage the insufficiency of the two opposed theses that divide accounts of Auschwitz: the view of humanist discourse, which states that "all human beings are human" and that of anti-humanist discourse, which holds that "only some human beings are human." What testimony says is something completely different, which can be formulated in the following theses: "human beings are human insofar as they are not human" or, more precisely, "human beings are human insofar as they bear witness to the inhuman" (Agamben 1999, 121).

So what is the human being after all? What remains of the human being after Auschwitz? And what about its future? Agamben is ultimately persuaded that "it is truly not possible to destroy the human" (Agamben 1999, 133-134), and this is due to the very specificity of the human being - that is, his or her own paradoxical and ambivalent feature:

The human being can survive the human being, the human being is what remains after the destruction of the human being, not because somewhere there is a human essence to be destroyed or saved, but because the place of the human is divided, because the human being exists in the fracture between the living being and the speaking being, the inhuman and the human (Agamben 1999, 134).

In other words, "the human being is a potential being" (Agamben 1999, 134), whose deeds and achievements are characterised by ambivalence and uncertainty-that is, by the unavoidable twofold possibility of achieving humanity against inhumanity (that is, preserving the fracture or differentia between the human and the inhuman) or reducing humanity to inhumanity (that is, getting rid of the fracture). By the way, what ambivalence additionally means is precisely that choosing one alternative does not imply the definitive vanishing of the other, but only its provisional relegation to the background of 
sheer possibility. And this is where human ambivalence and vulnerability cross: no matter how good or evil, any deed is always unsecure and provisional, since it is intrinsically vulnerable to its opposite: good is always exposed to the possibility of evil, and vice versa.

What in particular Auschwitz emphasises, is that when humanity is likely to be reduced to inhumanity, two main results follow: on the one hand, the human ambiguity nurtures evil and discharges dreadful effects on those, who become the persecuted and undergo extermination; on the other hand, thanks precisely to those vulnerable persecuted, who bear testimony to the atrocity, something of the human always remains, and this highlights an additional connection between the paradox of human ambivalence and vulnerability.

I believe Jonas' and Grossman's reflections on the Shoah are thoroughly consistent with these profound meditations by Agamben. First, Jonas and Grossman succeed in highlighting the essential vulnerability and ambivalence viz. the fracture that characterises human freedom. This not only means that human liberty can turn to good or evil, but also that there is no way of preemptively securing liberty against risks such as (self-)destruction, degradation, etc. And of course, due to the achievements of present day technology, the occurrence of such risks is far more than a mere theoretical possibility. Second, Jonas and Grossman face the similar challenge of reshaping their faith in humanity after the event of Auschwitz. Their intellectual itinerary witnesses this very effort, along with their personal involvement in the investigated matter. For both, the Shoah represents the crucial test to their reflections on human nature and the decisive proof of the inadequacy of a certain theoretical attitude, namely the one fostering an abstract and one-sided view of the human being. In this respect, Jonas and Grossman have to carry out different tasks: Jonas, who does not want to relinquish the idea of transcendence, undertakes a thorough and innovative rehabilitation of the latter that ends in de-potentiating the very notion of God, abandoning its traditional omnipotence and almightiness, while incredibly enhancing the ambivalent prerogative of human freedom and responsibility; instead Grossman, who preliminarily opts for an immanent perspective on humanity, has to enquire whether his abjuration of Soviet Communism affects his faith in humanity, and pays a fee in terms of personal sufferings and tribulations (he finally pays with his life) in order to corroborate it. The result is a fragile but invincible faith in humanity, one that succeeds in bearing witness to inhuman times.

For these reasons, I believe that Jonas' and Grossman's reflections on Auschwitz belong neither to the humanist, nor the anti-humanist perspective, but to the one focusing on the paradoxical fracture within the human being, and on the unforeseeable, vulnerable, and ambivalent viz. double-faced character of all that is human. 


\section{Concluding Remarks}

In this article I endeavoured to focus on the thinking of two authors of Jewish origins: the philosopher, Hans Jonas, and the writer, Vasily Grossman. In particular, I was interested in highlighting their contribution to the understanding of the Shoah. So, after a biographical outline I analysed how Jonas' and Grossman's works cope with the evil of Auschwitz, which indirectly hit them both (their mothers were exterminated by the Nazis in Auschwitz and Berdichev respectively). After an enquiry into the uniqueness of Auschwitz's evil, I focused on issues such as vulnerability, freedom, immortality, and humanity, and I tried to point out the analogies and differences between the works of the two authors. Among the affinities, I tried to single out the essential ambivalence of human nature, an ambivalence that characterises human liberty in a peculiar way: both Jonas and Grossman emphasise that the understanding of the Shoah requires them to reframe the fabric of their concepts, including personal freedom, and their idea of humanity. The latter can no longer be interpreted as something simply transcending history, or as untouched by immorality, wickedness, and inhumanity. On the contrary, Auschwitz undermines the utter distinguishability of good from bad, and humanity from inhumanity. And yet state both Jonas and Grossman-it is possible to preserve belief in humanity and in the good. This suggestion is not only one of the main achievements of Hans Jonas' and Vasily Grossman's reflections, but-as I tried to underline in the last paragraph-is also consistent with Giorgio Agamben's recent and relevant contribution to the topic.

\section{References}

Agamben, G. 1998. Homo Sacer. Sovereign Power and Bare Life. Stanford: Stanford University Press.

- - 1999. Remnants of Auschwitz. The Witness and the Archive. New York: Zone Books.

Arendt, H. 1994. Essays in Understanding 1930-1954. Formation, Exile, and Totalitarianism. New York: Harcourt Brace.

- - . 2003. Responsibility and Judgement. New York: Schocken Books.

- - - 2006. Eichmann in Jerusalem. A Report on the Banality of Evil. London: Penguin.

Badii, R. \& D'Andrea, D. (Eds.) 2014. Shoah, modernità e male politico. MilanoUdine: Mimesis.

Becchi, P. 2008. La vulnerabilità della vita. Contributi su Hans Jonas. Napoli: La Scuola di Pitagora. 
Becchi, P. 2010 Hans Jonas. Un profilo. Brescia: Morcelliana.

Becchi, P. \& Franzini Tibaldeo, R. 2014. "Né darwinismo, né intelligent design. Un confronto tra Hans Jonas e Joseph Ratzinger." In Annuario Filosofico 29: 242-275.

Bit-Yunan, Y. \& Chandler, R. 2013. "Introduction." Forward to: Grossman (2013): pos. 30-150.

Böhler, D. (Hrsg.) 1994. Ethik für die Zukunft: im Diskurs mit Hans Jonas. München: Beck.

Bohr, F., Meyer, C., \& Wiegrefe, K. 2014. „Das hat jeder mitgekriegt.“ Interview with Jakob W. Der Spiegel 35, 25 August 2014: 36-40.

Bonaldi, C. 2007. Hans Jonas e il mito. Tra orizzonte trascendentale di senso e apertura alla trascendenza. Vercelli: Mercurio.

Bonaldi, C. 2009. Hans Jonas. Roma: Carocci.

Bongardt, M. 2008. „Immanente Religion oder idealistische Spekulation? Zum Verhältnis von Gott und Mensch im »Gottesbegriff nach Auschwitz« von Hans Jonas". In Böhler, D., Gronke, H., \& Herrmann, B. (Hrsg.), Mensch - Gott - Welt. Philosophie des Lebens, Religionsphilosophie und Metaphysik im Werk von Hans Jonas. Freiburg - Berlin - Wien: Rombach: 173-189.

Borghese Keene, E. 2014. Hans Jonas, Mythe, temps et mémoire. Hildesheim: Olms.

Bori, P. C. 1990. La Madonna di San Sisto di Raffaello: studi sulla cultura russa. Bologna: il Mulino.

Curletto, M. A. 2006. "Nota di edizione." In Grossman, V., La Madonna a Treblinka. Milano: Medusa: 41-45.

D’Andrea, D. \& Badii, R. (Eds.) 2010. Sterminio e stermini. Shoah e violenze di massa nel Novecento. Bologna: il Mulino.

Dell'Asta, A. 2007. "Dal sogno all'incubo. Nazismo e comunismo in Vasilij Grossman." Forward to: Maddalena - Tosco 2007: 41-67.

Dries, Ch. 2012. Die Welt als Vernichtungslager. Eine kritische Theorie der Moderne im Anschluss an Günther Anders, Hannah Arendt und Hans Jonas. Bielefeld: Transcript.

Ehrenburg, I. \& Grossman, V. (Eds.) 2002. The Complete Black Book of Russian Jewry. New Brunswick (NJ): Transaction Publishers.

Ellis, F. 1994. Vasily Grossman. The Genesis and Evolution of a Russian Heretic. Oxford: Berg.

Franzini Tibaldeo, R. 2009. La rivoluzione ontologica di Hans Jonas. Uno studio sulla genesi e il significato di »Organismo e libertà." Milano-Udine: Mimesis.

Fraser, D. 1999. "Dead Man Walking: Law and Ethics after Giorgio Agamben's Auschwitz." International Journal for the Semiotics of Law 12: 397-417.

Frogneux, N. 2001. Hans Jonas ou la vie dans le monde. Bruxelles: De Boeck \& Larcier. 
- - - 2011. "Les conditions transhistoriques d'une juste liberté humaine: une lecture de Hans Jonas." In Bouton, Ch. \& Bégout, B. (Eds.), Penser l'histoire de Marx aux siècles des catastrophes. Paris: Editions de L'Eclat: 181-193.

———. 2012. "Une liberté responsable et décentrée à l'égard de la nature. Lecture anthropologique du "Principe responsabilité«." In L'art $d u$ comprendre - herméneutique générale, anthropologie philosophique, anthropologie phénoménologique, Daseinsanalyse. Vol. I. La nature et son souci, no. 21: 165-185.

Garrard, J. \& Garrard, C. 1996. The Bones of Berdichev. The Life and Fate of Vasily Grossman. New York: Free Press.

Grossman, V. 2010. The Road. Short Fiction and Articles. London: Maclehose Press.

-—- 2011a. Life and Fate. London: Vintage.

- - 2011b. Everything Flows. London: Vintage (Kindle Edition).

- - . 2013. An Armenian Sketchbook. London: Maclehose Press (kindle edition).

Hillesum, E. 2002. Etty: The Letters and Diaries of Etty Hillesum 1941-1943. Grand Rapids (MI): Eerdmans.

Hintzen, H. 2012. Paul Raphaelson und Hans Jonas. Ein jüdischer Kapo und ein bewaffneter Philosoph im Holocaust. Köln: Greven.

Jonas, H. 1930. Der Begriff der Gnosis. Inaugural-Dissertation zur Erlangung der Doktorwürde der Hohen Philosophischen Fakultät der PhilippsUniversität zu Marburg. Göttingen: Hubert.

-_- 1934. Gnosis und spätantiker Geist. Vol. I, Die mythologische Gnosis. Mit einer Einleitung "Zur Geschichte und Methodologie der Forschung." Göttingen: Vandenhoeck \& Ruprecht.

- - . 1954. Gnosis und spätantiker Geist. Vol. II, Chap. 1, Von der Mythologie zur mystischen Philosophie. Göttingen: Vandenhoeck \& Ruprecht.

- - . 1966. The Phenomenon of Life. Toward a Philosophical Biology. New York: Harper \& Row.

- - - 1974. Philosophical Essays. From Ancient Creed to Technological Man. Englewood Cliffs: Prentice-Hall.

- - 1984 [1979]. The Imperative of Responsibility. In Search of an Ethics for the Technological Age. Chicago: University of Chicago Press.

- - . 1985. Technik, Medizin und Ethik. Praxis des Prinzips Verantwortung. Frankfurt am Main: Insel.

- - 1992. Philosophische Untersuchungen und metaphysische Vermutungen. Frankfurt am Main: Insel.

Jonas, H. 1996. Mortality and Morality. A Search for the Good after Auschwitz. Evanston (Ill.): Northwestern University Press.

2008. Memoirs [2003]. Waltham (MA): Brandeis University Press and Hanover (NH): University Press of New England. 
Lévinas, E. 1996 [1984]. "Peace and Proximity." In Id., Basic Philosophical Writings. Bloomington (IN): Indiana University Press: 161-169.

Maddalena, G. 2007. “»L'umano dell'umano«: Vasilij Grossman e il possibile esito felice della vita." Forward to: Maddalena \& Tosco (2007): 251264.

Maddalena, G. \& Tosco, P. (Eds.) 2007. Il romanzo della libertà. Vasilij Grossman tra i classici del XX secolo. Soveria Mannelli: Rubbettino.

Mrówczyński-Van Allen, A. 2013. Between the Icon and the Idol: The Human Person and the Modern State in Russian Thought and Literature Chaadayev, Soloviev, Grossman. Eugene (OR): Cascade Books.

Pirazzoli, E. 2013. "Lo sguardo della Madonna Sistina." In il Mulino, 19 April 2013.

Ravenna, M. 2014. "Come pecore al macello? Ebrei nella Shoah e reazioni alla persecuzione." In Rivista Internazionale di Filosofia e Psicologia 5(1): 102-124.

Riconda, G. 2007. La »religione« di Grossman. Forward to: Maddalena-Tosco (2011): 221-250.

Todorov, T. 2003. Hope and Memory: Lessons from the Twentieth Century. Princeton (NJ): Princeton University Press.

Tosco, P. (Ed.) 2011. L'umano nell'uomo. Vasilij Grossman tra ideologie e domande eterne. Soveria Mannelli: Rubbettino.

Wiegrefe, K. 2014. „Die Schande nach Auschwitz.“ Der Spiegel 35, 25 August 2014: 28-35.

Wiese, Ch. 2007. The Life and Thought of Hans Jonas: Jewish Dimensions. Hanover (NH): University Press of New England Press.

Wolters, G. 2004. Vertuschung, Anklage, Rechtfertigung. Impromtus zum Rückblick der deutschen Philosophie auf das »Dritte Reich."Bonn: University Press.

. 2013. Hans Jonas e il razzismo. Lecture delivered at the congress »In ricordo di Hans Jonas, a vent'anni dalla morte« (Rome, October 2013). Retrieved from http://www.uni-konstanz.de/philosophie/files/jonas2013-roma\%2Bzusatz_1_.pdf on 10 Nov. 2014. 


\title{
Roberto Franzini Tibaldeo (Pisa)
}

\section{Hans Jonas and Vasily Grossman: \\ Reflections on the Human Condition after Auschwitz}

\begin{abstract}
The article endeavours to compare the reflections on the Shoah of two of the most celebrated intellectuals of Jewish origin of the 20th century, namely the German philosopher Hans Jonas (1903-1993) and the Soviet writer Vasily Grossman (1905-1964). Both Jonas' essay on The Concept of God after Auschwitz (1987) and Grossman's novels and reports, such as The Hell of Treblinka (1944), Life and Fate (1980), and The Sistine Madonna (1989), are characterised by a thorough enquiry into the ambivalence of the human condition, that tries to shed some light on the disturbing abyss of Auschwitz and the Shoah. Although neither Jonas nor Grossman considered themselves as religious believers, thanks to the Shoah they recollected their Jewish roots and developed peculiar and innovative thoughts on the meaning and vulnerability of life, human freedom, immortality, and God. The article endeavours to highlight the main similarities and differences between these two authors, who tackled the issue of thinking after Auschwitz.
\end{abstract}

Keywords: Hans Jonas, Vasily Grossman, Giorgio Agamben, Auschwitz, Shoah, vulnerability, immortality, human nature, human condition.

Doi: 10.14746/eip.2014.2.15 